\title{
Elicitive Conflict Mapping: A Practical Tool for Peacework
}

\author{
Josefina Echavarría Álvarez \\ Illustrations by Saskia Sievert
}

Submitted: October 2013

Accepted: June 2014

Published: November 2014

\section{Abstract}

This article presents the tool of elicitive conflict mapping (ECM), developed by Wolfgang Dietrich (2012, 2013, unpublished) at the Innsbruck UNESCO Chair and MA Program in Peace Studies, which seeks to operationalize the philosophy of transrational peace and the art of elicitive conflict work. The art of elicitive conflict work is based on the guiding principle that elicitive transformation does not develop or offer a content solution for the conflict episode, but provides a safe space for the parties, in which they can work on changes in their relationships along the horizons of their own intelligibility. In this context, the practical relevance of ECM is not the creation of prescriptive methods or recipes, because transrationality and elicitive work exclude such instruments, but to support conflicting parties in finding orientation and recognizing new and concrete courses of action in their own contexts. Read in conjunction with Dietrich's article, also in this issue, and methodologically inspired by mind mapping, this contribution surveys practical ways in which elicitive conflict workers can find a point of entry into conflict analysis and seek guidance in the complex reality of themes, layers and levels. The aim is to shed light on the steps that elicitive workers and facilitation teams can take in order to create possibilities and courses of action that enable the recovery of the dynamic equilibrium of the conflictive system.

\section{Keywords}

conflict mapping, transrational peace, elicitive conflict transformation, facilitation, conflict analysis and intervention

\section{INTRODUCTION}

How can elicitive conflict workers put into practice the knowledge and experiential insights of transrational peace? This is the main question that has guided the creation of Elicitive Conflict Mapping (ECM) as a tool for peace workers - including students, researchers and trainers - to orient themselves in the complex reality of the conflict.

This article brings to paper the ECM project developed by the UNESCO Chair and MA Program in Peace Studies as an online component, available on our homepage. ${ }^{1}$ The map was created by Wolfgang Dietrich and will soon be

\footnotetext{
1 http://www.uibk.ac.at/peacestudies/ecm/
}

Figure 1. ECM mind map

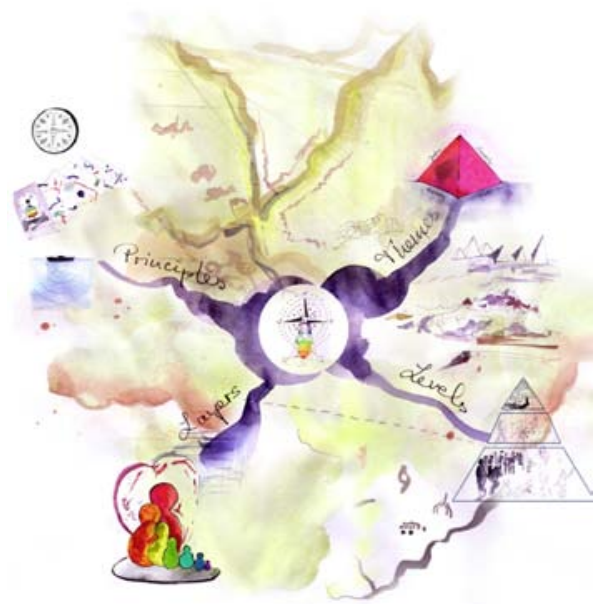


published in book form as the third volume of his trilogy Many Peaces (Dietrich, unpublished). In this article, we venture into a concise explanation of this method, hoping that it is useful and inspiring for elicitive conflict workers, but furthermore for all those peace scholars and practitioners who embrace the art of conflict transformation.

Based on the principles of elicitive conflict transformation and the transrational model (see Dietrich in this issue), ECM is not directed at an idealized destination in the distant future, but towards the question: In which direction can the next step be taken in order to maintain or recover the balance of the system? Precisely because social systems and their conflicts are always complex, such orientation is necessary.

In the same spirit of providing orientation and not a ready-made technical manual, the article is organized as follows: in the first section, an explanation of the main elements that appear on the map is provided. Then a few methodological pointers are given to choose the point of entry into the conflict analysis. The bulk of the work focuses on the themes, layers and levels of conflict analysis. Lastly, some practical insights are provided in the form of possible uses of ECM for the elicitive conflict worker, for the team of facilitators and as a method for the conflicting parties.

\section{UNDERSTANDING THE ECM MIND MAP}

In order to be able to use ECM as a working method, it is important to first familiarize oneself with the different concepts that appear on the map.

Figure 2. The elicitive conflict worker

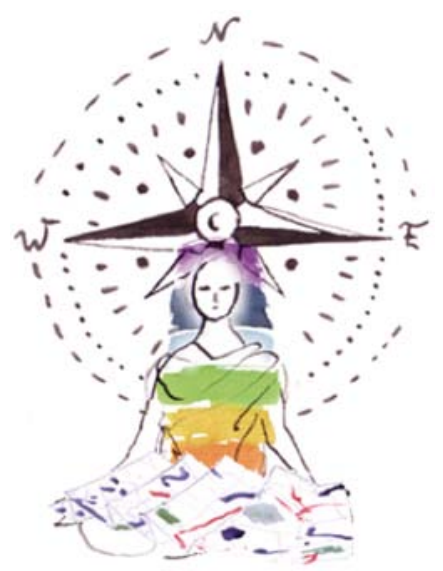

In the center of the map we have the symbol of the elicitive conflict worker. In the second volume of Many Peaces (Dietrich, 2013) as well as in Wolfgang Dietrich's contribution to this issue, the profile of the elicitive conflict worker is detailed.

Starting from the image of the elicitive conflict worker, there are several branches which connect to the main concepts: principles, themes, layers and levels.

Figure 3. Principle of correspondence

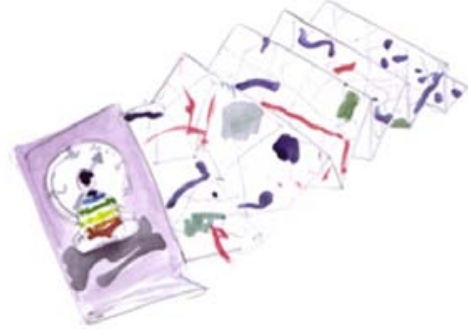

Figure 4. Principle of homeostasis

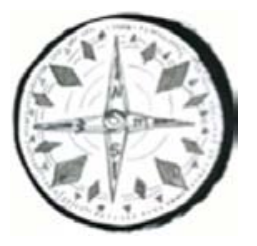

Figure 5. Principle of resonance

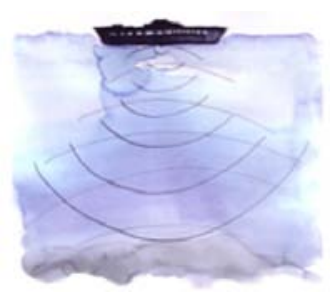

The principles help orient the conflict worker in each of the other branches of the mind map. They are valuable for preparation and implementation of conflict interventions, both for the team and the elicitive worker him/herself.

Figure 6. Theme pyramid

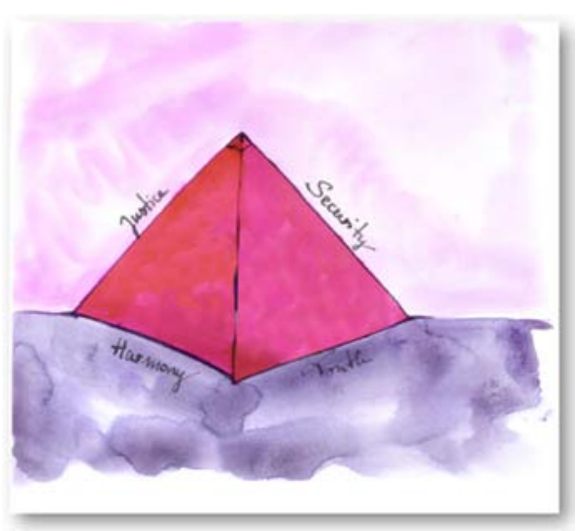


The themes relate to the main thematic narrative of the conflict episode, as discerned by the elicitive worker. In this area, a concise explanation of the different variations of peace, i.e. energetic, moral, modern, postmodern and transrational, and the themes of harmony, justice, security and truth are found.

Figure 7. Complete layers

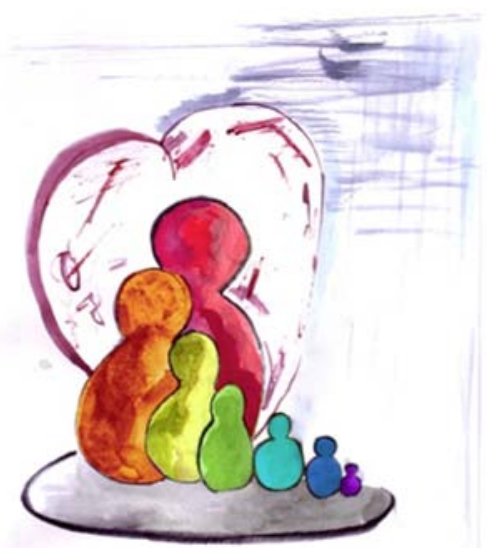

The layers offer a journey through the persona and her sexual-family, socio-emotional-communal, mental-societal, spiritual-policitary and global awareness layers.

Figure 8. Levels of the pyramid

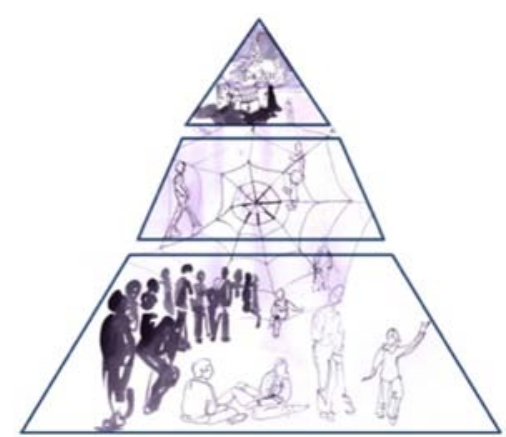

The levels of the conflict pyramid are made up of the different actors, i.e. top level, middle-range and grassroots, and activities of conflict transformation from a systemic perspective, which are then integrated into the Sri-Yantra symbol.

\subsection{About the point of entry: Where to start?}

In terms of the practical application of elicitive conflict work, the first question concerns focus: which theme, actor, or group of actors is given priority. The practical elicitive conflict work may commence in any of the themes, layers and levels, from the intrapersonal and spiritual to the interpersonal and policitary (Dietrich, 2013, p. 206). In a similar vein, the elicitive conflict worker can order the basic ideas and start exploring the ECM mind map at any of these points. While in the online version of ECM this multiplicity and plurality might be easier to grasp for the user, for purposes of clarity, in this written version we have sketched a path to read the mind map as follows: Principles, Themes, Layers and Levels.

Figure 9. Team of facilitators

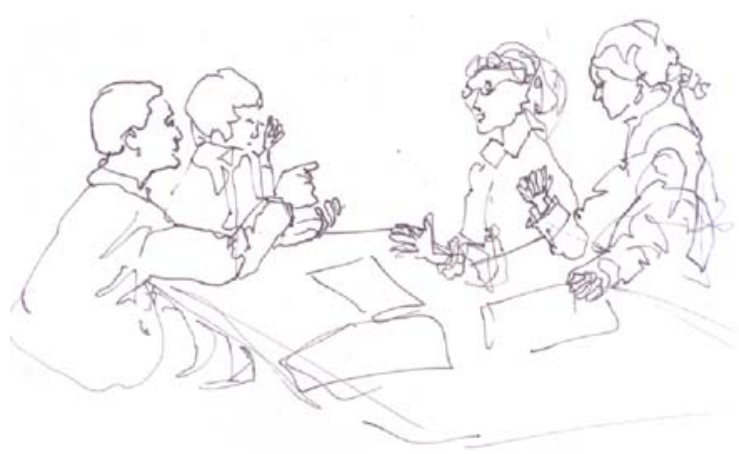

\section{PRINCIPLES}

ECM is the applied method of Transrational Peace Philosophy based on three principles: correspondence, resonance and homeostasis. While throughout the text these principles are weaved into themes, layers and levels, it is highly recommended that the reader familiarizes him/ herself with them beforehand. For this, see Dietrich in this issue. Once the three principles of ECM are understood, the mind map can also be seen as a system which has certain rules that guide its functioning, and also points out important considerations for the conflict worker in his/her analysis of the conflict.

\section{THEMES}

After gaining insight into the principles, we move forward in our approximation of the ECM towards the themes. This area of the map is of great value, since one of the most important first steps in the approximation to the conflict is to determine, identify or recognize the primary theme of the conflict episode.

"An episode of conflict is the visible expression of conflict rising within the relationship or system, usually within a distinct time frame. It generates attention and energy around a particular set of issues that need 
response. The epicenter of conflict is the web of relational patterns, often providing a history of lived episodes, from which new episodes and issues emerge. If the episode releases conflict energy in the relationship, the epicenter is where the energy is produced." (Lederach, 2003, p. 31)

As Lederach suggests, the storyline of the conflict has a primary theme, a central topic that dominates the narrative, which is a conglomerate of issues towards which the energy is being pulled. Elicitive conflict workers might have an implicit or an explicit mandate that touches or is built upon such conflict narrative. This narrative can be the representation of the conflicting parties that are seeking help themselves or through institutions, which might previously have been involved as third parties (Dietrich, 2013).

In Transrational Peace Philosophy, we named the four main themes Harmony, Justice, Security and Truth, which at the same time speak of different variations of peace, the so-called Peace Families.

\subsection{The five Peace Families}

In the face of the reduction of peace to its mainly normative significance, both in theory and practice, during the past two decades Wolfgang Dietrich $(2011,2013)$ has developed a systematization of different variations of peace, the so-called five Peace Families. This plural outlook on peace allows the elicitive conflict worker to recognize at the start the tendencies and characteristics of the peace notions that are prevalent in the context that occupies him/ her, how these function and, by definition, to be aware of the variations of peace that might have been left on the side and whose recovery might help to bring a dynamic equilibrium back into the system.

While Interpretations of Peace in History and Culture (Dietrich, 2011) details these families, for the purposes of ECM, here we describe the main elements and main thematic emphases of Energetic, Moral, Modern, Post-Modern and Transrational peace approaches.

\subsubsection{Energetic peace}

Energetic peaces are holistic. They perceive all existence as a fabric interrelating nature, society and divinities (cosmos). The individual is never separate, but always part and parcel of the larger relationality that, in turn, is ultimately a temporary manifestation of the primal energetic Oneness of all beings. (Echavarría et. al., 2011)
Figure 10. Energetic peace

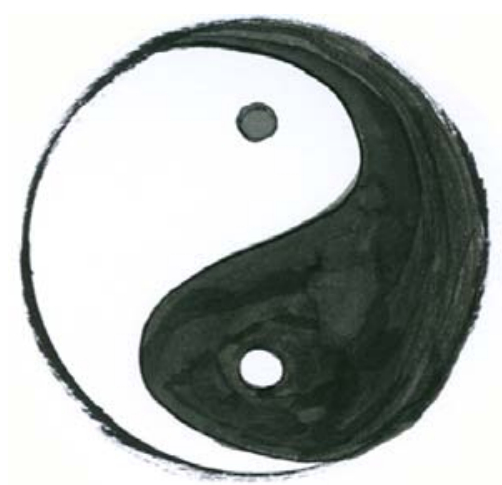

In these energetic approaches, peace is understood as a unification of opposites. With our human senses, we perceive different polarities. Peace is a question of how to balance them. It is assumed that such balance, in an energetic manner, can only be thought of as a dynamic equilibrium. Therefore, there is no permanent final state or situation, but an ongoing challenge to balance both the intra- and inter-personal layers of being.

Figure 11. Harmony

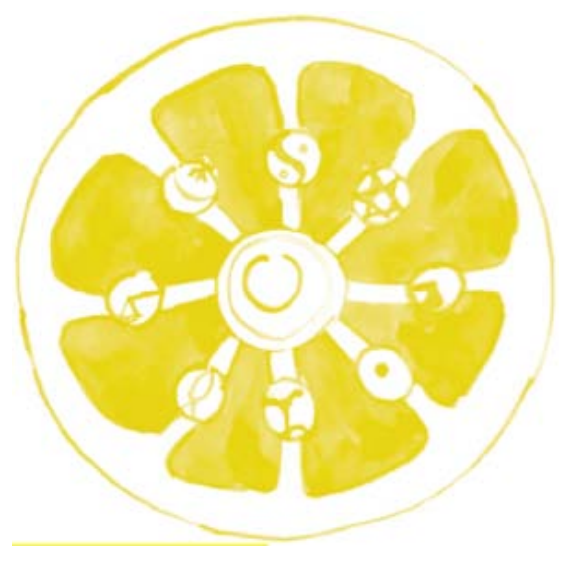

Based on the above, the thematic tendencies of energetic peaces revolve around issues of harmony, as perceived by the experiencing subject within this relationality, and we can observe how they consistently aim at a dynamic balance between society, nature and cosmos.

\subsubsection{Moral peace}

Moral understandings of peace are organic. The material world and everything in it is perceived as an interconnected whole, but the realm of the divinities is separate. While the initial observation of living in a world of polarities coincides with that of energetic peaces, the conclusion derived in moral approaches is quite different: polarities are 
interpreted as a dualism between true and false, good and evil, right and wrong, strong and weak. In the face of these polarities, whether in nature or society, the question that arises is how to achieve peace via doing good and overcoming evil.

Figure 12. Moral peace

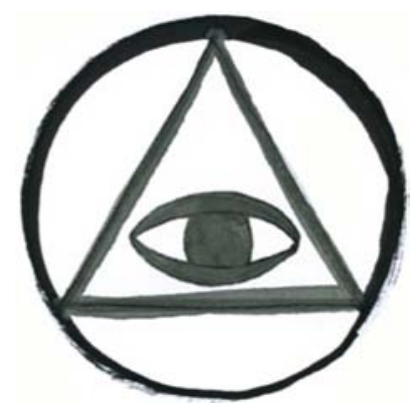

To reach such a decision, absolute norms of conduct and values are provided by a single, personified (male) creator, God, who brings the universe into existence yet Himself stands apart from it. He is an acting agent and peace shall be the reward for those following His rules. The rules, in turn, call for institutions and experts to authoritatively interpret and explain His law to the people. True peace remains a transcendent matter to be realized by those following moral norms.

Figure 13. Justice

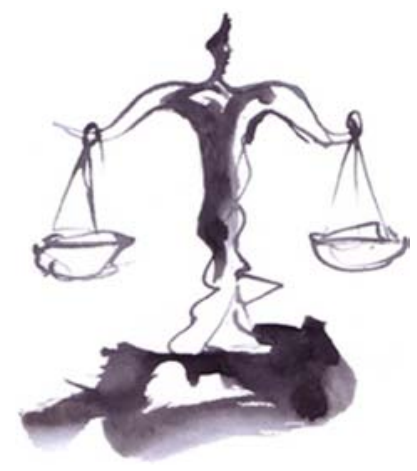

Based on the above, we can identify a further thematic tendency for moral peaces: the question of Justice.

"Peace through justice is not perceived in the present, but postponed to a better future (...). Once the linear understanding of social time inherent in moral approaches is connected with the material aspect of justice, the ground is laid for an ideology marked by: revenge for past injustices, envy in the present, and hunger for justice in the future, which develops an explosive concoction that easily justifies wars and violence." (Dietrich, 2013, p. 196)

\subsubsection{Modern peace}

Modern peaces are mechanic. The spiritual realm is neglected in favor of a purely this-worldly perception of the universe. While God served as the founding principle in moral approaches to peace, $\mathrm{He}$ is replaced by rationality as the founding principle of peace in modern interpretations. From this derives the modern concern with earthly relations and the idea that only that which can be apprehended by the senses is of relevance for peace (Echavarría et al., 2011).

Figure 14. Modern peace

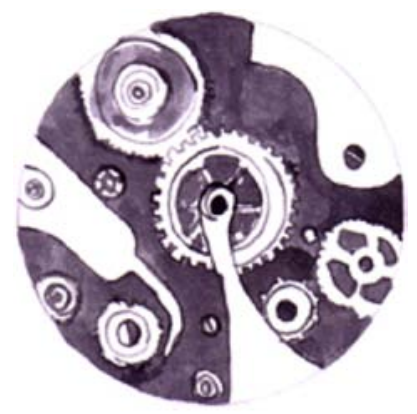

In a modern, secular understanding, the universe functions like a machine according to eternal laws of cause and effect that, via the natural sciences, can, at least in principle, be deciphered. The same notion applies to the human realm, where knowledge of the functioning of the individual and society paves the road towards the possibility to actively perfect the human condition and achieve peace. Peace becomes the promise of a final stage of human evolution, reinforced by a linear understanding of history guided by the belief in progress, enlightenment, development or civilization.

Figure 15. Security

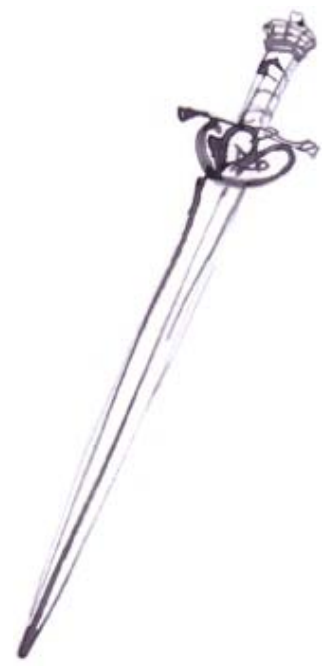


We can recognize how, in modern concepts of peace, there is a thematic tendency to highlight security in conflict episodes, where we find peace in direct relation to the material sphere, where things can be seen, measured and accumulated. The fear of losing them, including the fear of losing one's life, becomes a high risk, which has to be managed in a safe place. This is also the assurance of the nation-state as a political entity that promises to maintain internal order for the citizens inside its borders and keep them safe from the invasion of foreigners, perceived as external threats.

\subsubsection{Postmodern peace}

Postmodern peaces co-emerge with modern ones, as their critical and doubting counterparts. The postmodern state of mind ensues whenever the promises of modernity are no longer believed. Postmodernity thus refers to the disillusionment, disbelief and fear created by modernity's wars and violence, whenever the promises of 'peace out of security' reveal the harm they inflict and the pain they cause (Echavarría et al., 2011). To find orientation in this devastation, plurality appears as the key term for postmodern philosophy.

Figure 16. Postmodern peace

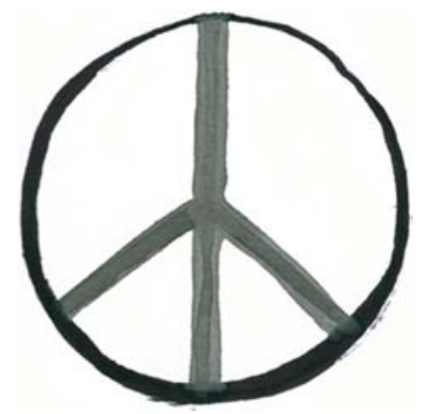

Abstaining from a modern foundation in singularity and embracing plurality, postmodern understandings of peace celebrate the multiplicity of existence without looking towards a resolution of tension between contradictions. They rather 'twist' the dogmatism of modernity's reason, thereby turning its analytical tool on itself.

Therefore, postmodern understandings remain small, local and contextual. They do not promise hope for reconciliation in non-dual Oneness, or provide certainties. Since there is no source of ultimate authority, peaces can only be defined in concrete encounters. They need to be reinvented and struggled for anew, since they perpetually remain transitory and unstable.
Figure 17. Truth

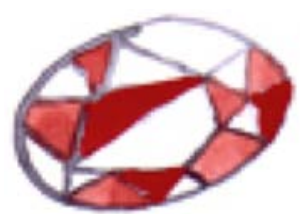

Based on the above, we see how the question of truth gains special importance in postmodern approaches to peace. By refraining from a singular modern truth, postmodern peaces necessarily call for the existence of plural notions of truth. Postmodern peaces seek to find truth in every human encounter, which creates many different variations of truth relative to each encounter, because only those who are involved can define what truth means to them, in their particular context. The result then is a plurality of truths in peace research and practice, hence "many peaces" (Dietrich and Sützl, 2006).

\subsubsection{Transrational peace}

Transrational peaces share the postmodern commitment to plurality, but also reintegrate the spiritual component. Trans-rational implies having passed through the rational, but without clinging to its purely materialistic perspective. Reason is acknowledged as one possible mode of perception, among others (Echavarría et al., 2011).

Figure 18. Transrational peace, the Sri-Yantra symbol

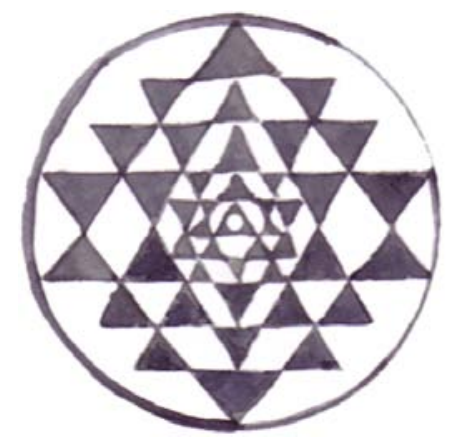

Philosophical and scientific approaches based on transrationality deal with the lack of founding from a so-called bootstrap approach, i.e. accepting a multiplicity of overlapping yet not completely coinciding viewpoints, a shifting of perspectives between overlapping lenses that never completely merge. Their descriptions of reality differ and the spiritual might as well be expressed in terms of a systemic approach, of deep-ecology, as transpersonal or yet again the holistic. 


\subsection{Thematic shifts}

Transrational peaces take the four thematic emphases of the peace families and combine the knowledge and relevance of each of them. ${ }^{2}$ Transrationality recognizes the need for personal harmony, relational security, structural justice and cultural truth for the existence of peace, yet instead of focusing on one of these themes, transrational peaces seek the dynamic equilibrium of the following four topics:

- "The transrational interpretation of peace includes the energetic worldview and considers the role played by harmony and vibrations in social contexts" (Dietrich, 2013, p. 106). Inasmuch as harmony is a physical, biological, intellectual, and psychological process in interpersonal encounters, it is necessarily a basic element of peace.

- "Justice is addressed as an issue of the subjective and communal satisfaction of needs, rather than the mechanistic meeting of a demand. Growth is understood as a process, not in teleological terms as a purpose in itself. The focus is on what we already are and what we need right now, and not on what we should do in order to live up to the definition of a future ideal." (Dietrich, 2013, p. 198).
- New wars and the 1992 UN Agenda for Peace have become practical and conceptual guides to understand that, from a transrational angle, in the $21^{\text {st }}$ century we have moved from a sovereign to a relational type of security. The latter is characterized by peace operations where civilian-military cooperation is the norm in missions. Soldiers then require a new profile that is no longer that of geopolitical security operators, which furthermore includes basic training in socio-psychological processes and, above all, "an awareness of how one's own behavior affects the local population" (Dietrich, 2013, p. 133).

- Transrational peaces take the notion of truth from postmodern approaches, embracing its call for pluralism, which paves the way for respectful communication across different cultural contexts (Dietrich, 2013, p. 180).

\subsection{Thematic emphases}

While there are no prescriptive formulas, considering the peace families' characteristics in line with their thematic preference, the episode of a conflict tends to be expressed in unmet needs, giving us clues as to which theme can be perceived as primary and thus mark the point of entry into the conflict (Dietrich, unpublished).

Table 1. Primary themes and their common expression in unmet needs

\begin{tabular}{|c|c|}
\hline Theme & Unmet needs in the episode \\
\hline Security & $\begin{array}{l}\text { Defense against attacks or invasion from perceived enemies, control over encounters, protected areas, demili- } \\
\text { tarized zones, disarmament, and border control, among others. At the grassroots level, it is often expressed in } \\
\text { the call for (more) police surveillance, safe houses, shelter for asylum seekers and demining, to name a few. }\end{array}$ \\
\hline Justice & $\begin{array}{l}\text { Demand for food, housing, clothing, medical care, as well as access to jobs, farmland, water, trade routes, re- } \\
\text { sources, information, and similar. }\end{array}$ \\
\hline Truth & $\begin{array}{l}\text { Demand for educational and political institutions, trade unions and prayer facilities, among many others. } \\
\text { These expressions have a tendency to be rationally selected interpretations of the world, such as ethics, reli- } \\
\text { gion, science, nationality and ideology. }\end{array}$ \\
\hline Harmony & $\begin{array}{l}\text { Complaints about the defects of others: as a consequence of a hermetic construction of the 'we', 'others' (they) } \\
\text { are perceived as a wrong, evil and disturbing group - whether 'they' identify themselves as a group or not, } \\
\text { 'they' are perceived as such by 'us. The physically excluded 'others' are categorized in a hermetic manner that } \\
\text { they cannot escape, for example 'youths', 'migrants', 'women', and so on. }\end{array}$ \\
\hline
\end{tabular}

2 In the philosophy of Transrational Peaces, we can order the four themes of harmony, justice, security and truth along the four quadrants proposed by Ken Wilber (2000, pp. 127-157, 192-199), which Wolfgang Dietrich (2011, pp. 251-254) has integrated into what is now called The Four Transrational Quadrants. In the first two volumes of the Many Peaces Trilogy, Dietrich $(2011,2013)$ explains the quadrant at length, and his contribution in this issue summarizes the main points. 
If the main topic is not evident, the conflict worker has a large pool of tools and skills that might help him/ her identify that primary theme. First, Active Listening in the spirit of Carl Rogers (Rogers and Farson, 1987; Rogers, 1995) is a highly recommendable communication exercise in order to make visible the main topic that keeps the parties involved in the conflict. By bringing in the four different steps of Non Violent Communication coined by Marshall Rosenberg (2005), namely observations, feelings, needs and requests, the elicitive worker might be able to identify the main theme when necessary.

\section{LAYERS}

Further branches in the ECM map are the layers. While in prescriptive approaches to conflict transformation the solution to the problems are looked for in the episode itself, approaching a conflict in an elicitive manner requires inquiring about the layers behind the episode. This is the reason why elicitive work does not first demand action or intervention, but analysis. Thus, after the primary theme has been identified, the elicitive conflict worker pays close attention to the layers that surround the episode. The principle of correspondence points to the connection between the inner and outer layers and to the equal importance of both sets of layers in the episode.

With the aim of making the layers visible and easier to work with in a practical setting, we follow the sevenchakra Yoga Philosophy, as taught by Sri Aurobindo (Dietrich, 2012, pp. 212-214), which is read as a single system of synchronic and corresponding elements reaching from the basic material needs of survival to the cosmic aspects of existence.

Figure 19. Transverse layers

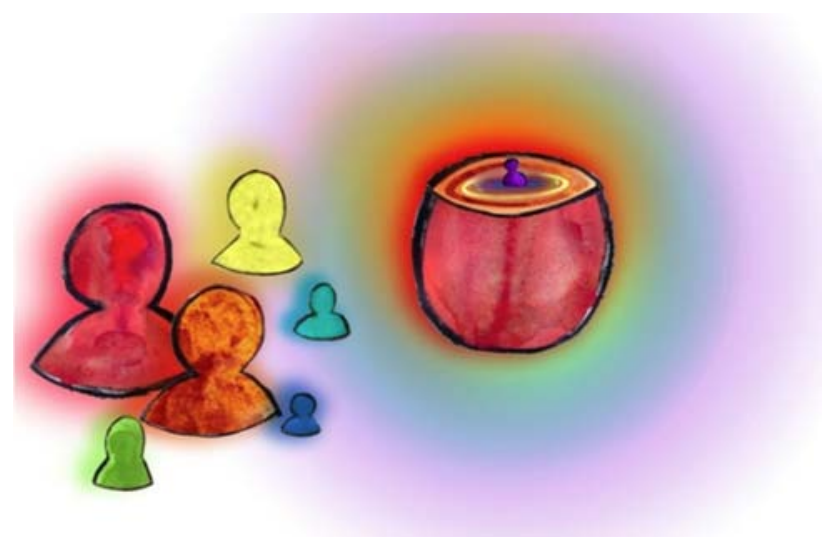

Frequently, conflicts push the deeper inner layers to the surface, where they are expressed as a material clash of interests. The conflict is rarely solved in a rational and argumentative manner in the episode, since, even after superficially successful events on the surface, the energy that nurtures the conflict in the epicenter will find a way to further create and invigorate new episodes through new themes, i.e. there will be a conflict transposition or translation (Dietrich, 2013, pp. 7, 222). Thus, elicitive conflict transformation should observe the deeper layers and, even as pointing with a finger on a map is not the same as traveling to that point, the layers described can provide orientation and clues as to how to deal with eventual blockages to the dynamic equilibrium of the system.

\subsection{Episode: Dance of the persona}

The dance of the persona represents the episodic surface of a conflict and is its most visible layer. It may circumscribe any of the large thematic fields of justice, security, truth, and harmony. The episode, the direct encounter of the conflicting parties, is the world of the word and the voice. "Elicitive peace workers know that from the surface of the episode the words and the vibrations of the voices of the conflict parties reach the inner layers of the self and the outer layers of the social context. Peace work encourages this process." (Dietrich, 2013, p. 208).

Figure 20. Persona

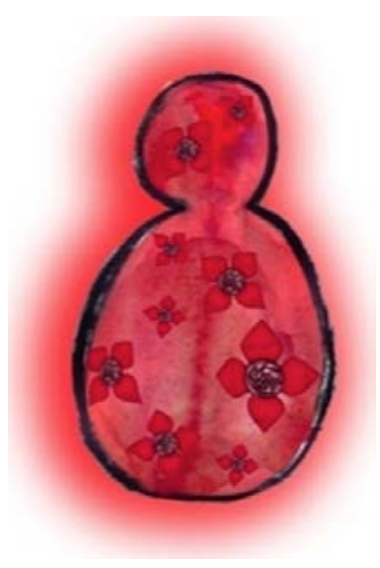

\subsection{Sexual-family layers}

Immediately under the surface of the episode, we find the family and sexual layers in which great potential lies if they are also understood as the svadhisthana chakra, to which is attributed creativity, instinct, sensitivity and the need to adapt to prevailing norms. Here lies both the big potential for explosion and transformation to be found at this first inner layer. 
http://journal-of-conflictology.uoc.edu

Figure 21. Sexual-family layers

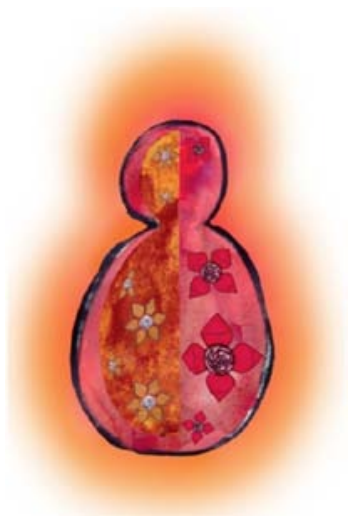

In order for the elicitive worker to find out whether there is dynamic equilibrium or a blockage in these layers, and in line with the principle of resonance, authentic communication and natural behaviour with the parties to the conflict are highly relevant. As a third party, also as someone that has arrived 'late' to the conflict, there is a need to be as open and clear as possible in order to sense the vibrations of the parties in this layer. If, on the basis of socialization, education or religion, or professional understanding or social restraints, the conflict worker is inhibited to be open enough, the appropriate communication from the parties might not be received.

\subsection{Socio-emotional - Communal layers}

Behind the sexual-family layers, we find the socio-emotional and communal layers, which give us a clear picture of the workings of the principle of resonance between the intra and the interpersonal spheres in elicitive conflict transformation. The need for social belonging and recognition is a natural intrapersonal dimension. In Yoga Philosophy, this layer stands for the manipura chakra, which signifies determination, ego, willpower, dynamism and expansion.
As persons, we naturally aspire to gain a recognized position in a community which lies beyond the immediate circle of the family or sexual partners and includes being accepted and respected, and belonging. If for any reason a person is deprived of social interaction, cooperation and recognition, this would lead to emotional harm, wounds and sickness of the persona in her ego-aspects (Dietrich, 2013).

Since there is a broader spectrum of dysfunctions at these layers than those of the sexual-family layers, the elicitive worker should orient him/herself differently. Following the principle of resonance, those who work on these layers have to be especially sensitive and empathic at this level, yet just as consciously structured and able to communicate with the parties with selective authenticity and flexibility.

\subsection{Mental-societal layers}

If we were to order these layers once more according to Yoga Philosophy, we would find the anahata chakra, which stands for the heart and mind.

\begin{abstract}
"The intrapersonal, mental aspect provides the persona with the potential of reason and consciousness. The intrapersonal and mental, as well as the interpersonal and social layers, comprise all the previously mentioned ones, and enable the persona and societies, precisely through this potential, to become conscious of the previously mentioned layers. (...) The heartbeat causes and symbolizes the life of the persona. And life transforms transrational qualities like love, compassion, and devotion, by bringing them into the episode in ways that can be grasped by the senses, and by rendering them conscious experiences. Thus, it is mental awareness that balances the sexual, family, and social energies in an episode." (Dietrich, 2013, pp. 215-216)
\end{abstract}
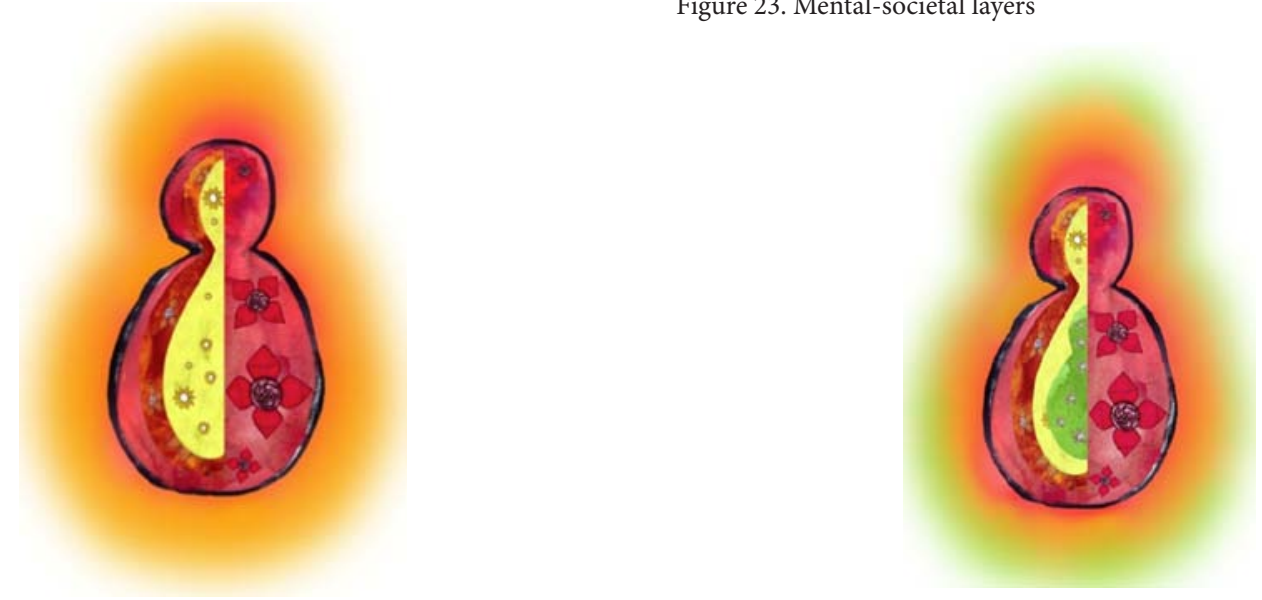
A conflict, whose episode is primarily an idea of the parties, tends to become an even more destructive clash when third parties feed even more arguments into it. In this case, a reorientation towards other layers is highly recommendable. Contrary to prescriptive models that follow the abstractly proposed resolution model of reason, elicitive methods use reason for working on the different impulses in all the layers that they perceive from the parties when acting in resonance. For conflict workers to be able to give this feedback without creating more distortions, they need mental clarity, whose precondition is a dynamic equilibrium of the worker him/herself at these very same mental and societal layers.

\subsection{Spiritual-policitary layers}

The persona's intrapersonal spiritual layer is located below the material, sexual, social, and mental layers. We can order it at the level of the visuddha chakra.

\begin{abstract}
"In intrapersonal terms, spirituality is located beyond consciousness and the ego's lines of defense. The spiritual layer emerges from the shadow cast by thoughts and emotions. Perception is released for the present, and the highest state of elicitive conflict work is reached - the perspective of the 'internal observer'. (...) Policity is the interpersonal equivalent to intrapersonal spirituality (...) or external observer who, like his or her intrapersonal equivalent, observes the dance of the personae in a loving fashion, without judgment and comparison, and without thoughts of reward or punishment." (Dietrich, 2013, p. 220)
\end{abstract}

Figure 24. Spiritual-policitary layers

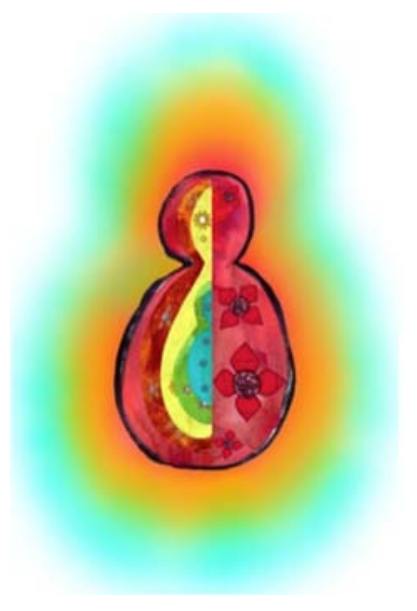

Following the principle of resonance, for someone to work on these layers it is indispensable that he/she is in balance him/herself. Therefore, it is important to get acquainted with these layers, for instance through practice and meditation, in order to explore one's possibilities and expand one's experiences. An elicitive worker who understands the parties to the conflict in a systematic and holistic manner and treats them accordingly, even in moral, modern and post-modern contexts, has the elicitive potential to have an impact on the episode and elicit new interpretations.

\subsection{Global layer}

Although the global layer is so far removed from the conflictive layers of the ego and its episodes, and thus is not put to use in applied conflict work, it does pervade it. Equivalent to the ajna chakra, this global layer is what makes it possible to experience peace, and thus is worth striving for and of course important when mapping conflicts (Dietrich, 2013, p. 223).

Figure 25. The global layer

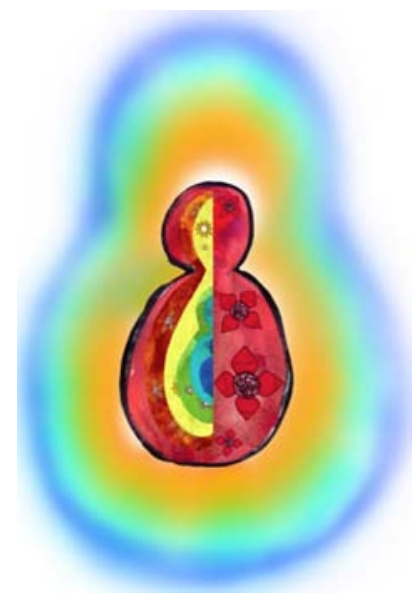

\subsection{The epicenter}

In a similar vein to the global layer, the universal layer equivalent to the sahasrara in chakra philosophy or the epicenter in conflict terms - is also beyond the scope of practical conflict work, yet it is paramount to include this layer in maps of the persona.

"While elicitive peace work may be deeply rooted in the epicenter, in the human space-time consciousness, it manifests in the dance of the persona, in the episode, and in the roles through which peace work is revealed in specific systems." (Dietrich, 2013, p. 224)

With the epicenter, we finish the journey through the persona and have a better comprehension of the 
different layers that are always at work in every conflict episode. This then enables us to continue the explanation of the mind map towards its last and final elements, i.e. the levels.

Figure 26. The epicenter

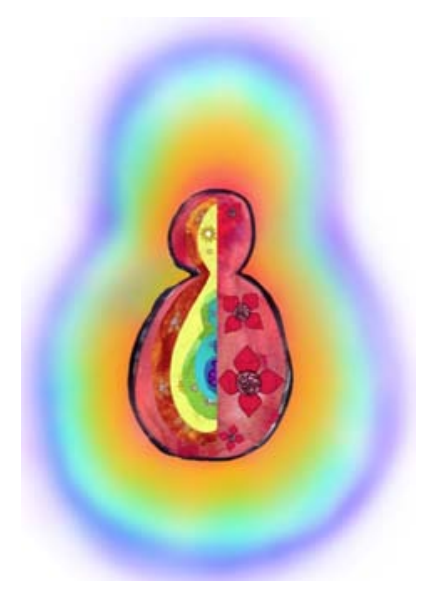

\section{LEVELS}

The ECM levels point to different actors in the conflict and in its transformation as a way of understanding their position, since this becomes crucial for the elicitive worker's analysis and intervention. These levels have been drawn following John Paul Lederach's (1997) vertical categories of Top, Middle Range and Grassroots Leaders. For the purposes of ECM, we have taken Lederach's insights and incorporated them into the Sri-Yantra symbol, as a way of emphasizing the transition from a structuralist-inspired understanding towards a systemic one.

The Top level of leadership "comprises the key political and military leaders" (Lederach, 1997, p. 38), as well as high-ranking religious institutions and big business management. At the second, Middle-Range level, we can find people "who are highly respected as individuals and/ or occupy formal positions of leadership in sectors such as education, business, agriculture or health" (Lederach, 1997, p. 41). Likewise, here we also count on networks, institutions and groups which are religious, academic or humanitarian, organized in non-governmental and transnational ways, reminding us of those who are classically inscribed in multitrack-diplomacy. Finally, "the grassroots represents the masses, the base of the society. Life at this level is characterized, particularly in settings of protracted conflict and war, by a survival mentality" (Lederach, 1997, p. 42).
Figure 27. Levels of the pyramid

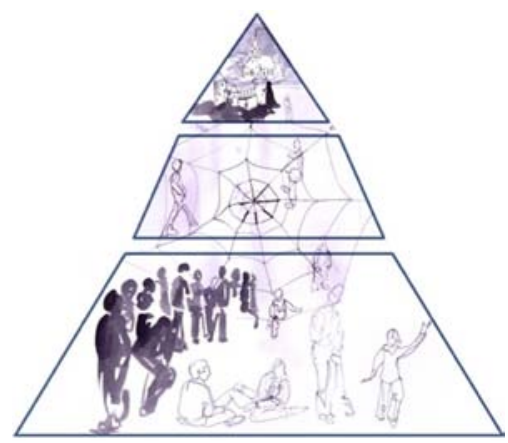

In its original version, Lederach's (1997) pyramid indicated that all actors interact across the various social strata, from the grassroots to the middle range of regional experts and leaders to heads of state, and that they are relevant to the process of transformation following the experience of violence. In figure 27, we have already seen the spider web that Lederach (2005, p. 82) included years later in The Moral Imagination, with the purpose of highlighting the nonmechanistic way of interpreting the pyramid. This means that, instead of a single direction in both top-down and bottom-up approaches to peace building, in this reworked version the interactions of the different actors affect one another in feedback loops, and so all actors influence each other in endless succession.

\subsection{Sri-Yantra}

Because a hexagon shape limits the spider web, in Transrational Peace Philosophy we use the symbol of Sri-Yantra to mirror the systemic character more accurately.

Figure 28. Transrational Peace / Sri-Yantra Symbol

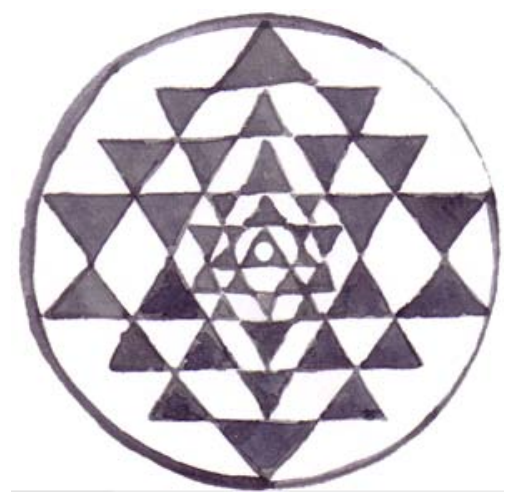

Since the figure is three-dimensional, it allows seeing the vertical feedback between the layers on the surface of the conflict episode, and furthermore shows its validity for the horizontal connections among the individual levels themselves, all the way up to the epicenter. 


\begin{abstract}
"When we see the Sri-Yantra as symbol also for the complexity of the themes, levels and layers, it shatters any representation of a definitive conflict resolution or prescriptive conflict transformation. The complexity of the world brings along an obligation to select, to reduce and to decide. In a dysfunctional social system, the decision for the parties - as well as for the conflict worker - is risky, since each decision carries a series of possibilities that have remained unconsidered or at least have not been put into practice. (...) As soon as we recognize this, guides for orientation are welcome. These are the guides for orientation that elicitive conflict transformation aims at providing." (Dietrich, unpublished).
\end{abstract}

\section{ECM AS WORKING METHOD}

For the creation of mind maps, Tony Buzan (2010) proposes the model of a tree, in which the main concept (a word or an image) is placed in the center, from which different branches are drawn, each of them signifying associated concepts. These branches can be drawn in a creative manner, without restrictions. From the branches, new concepts arise, which - at the same time - can become central concepts to start a new mind map, which resembles the radiant thinking of the brain and helps us imagine conflict transformation as a complex and creative exercise.

\subsection{Conflict images}

In the praxis of elicitive conflict transformation, a meaningful exercise is to place the main topic of the episode in the center and to position it on one of the sides of the thematic pyramid. Starting from there, raising the basic questions of what, where, how, when, who and why can become the first branches that shed light on the darker sides of the surrounding layers, or they can complete the perception of the episode.

As regards the actors of elicitive conflict transformation, we can use the ECM at least in three different ways.

\subsubsection{Individual orientation guide}

Through active listening and corresponding note taking, the elicitive conflict worker can first focus the narrative on one of the levels and on one of the central themes of the episode. From this central point and aware of the threedimensional system made up of themes, layers and levels, the conflict worker can then create an own mind map following his/her intuition and creativity. The principle of resonance with the conflicting parties ensures that the intuition and creativity of the conflict worker does not become self-referential. The principle of correspondence gives the map structure, without forcing or restricting it thematically. From the perspective of the episode, the deeper layers are found in the lower hierarchies. In praxis, a dysfunction in the deeper layers can be found under the surface of the narrative. If this narrative appears to be convincing, then both theme and level can be placed in the center of a new map. From this point onwards, further thematic branches can be created, which give orientation to the conflict work in the dysfunctional system. If the process is unsuccessful, it can be repeated and tried once again.

\subsubsection{Team organization}

In a second possible use for ECM, the main purpose is to gain a common visualization of the conflict situation and possible orientation for the conflict work. The map here serves as a means of communication that allows members of the team to dialogue with others about their thought structures and facilitates following up changes in the cognitive and discussion processes in an easy and democratic manner. The method here is open. Maps, for example, can be created individually or in small groups first and then put together, or all team members can work together on the same map, depending on size of the team and the task.

\subsubsection{In the transformation of the conflict}

A third possibility points to a fascinating use of ECM, i.e. as a transformation tool in and of itself. If the situation of the conflict intervention allows it, the basic rules of mind mapping can be communicated to the conflicting parties and they can create their own mind maps for working on the dysfunctional system. Tony Buzan (2010) proposes that each party creates at least three different maps: a map for the negative aspects of the relationships, a second one for the positive aspects and a third for possible solutions.

It is vital to remember that elicitive conflict transformation cannot tie promises of solutions to any of these creative methods, but the production of maps can very well bring hope for a wider understanding by the parties in the conflict situation, and also empathy for the concerns of the other parties. This increases creativity of the parties in the development of alternative courses of actions and enhanced capacity for resonance and insight into the urgency of a homeostatic equilibrium. When this occurs, the conflict energy on all layers can be used for constructive reshaping of the relationships and the transformation of the conflict, both rationally and transrationally. 


\section{CONCLUSION}

ECM is a practical tool that, through its multiple possibilities for use, offers elicitive conflict workers a large collection of viable courses of action to both analyze and intervene in conflict settings. This analysis can range from the themes and layers to the levels of the conflict and, as a working method, it can also be applied to the elicitive conflict worker him/herself, as well as be of use for the facilitation team and even for the conflicting parties.

In this way, ECM can shed light on concrete points of blockage in the system, as well as instigate possible ways of tackling them in a holistic manner. However, just like the map must not be confused with the territory, we also encourage our readers to use these insights in combination with the necessary work on the self that elicitive conflict transformation demands. In order to catalyze the conflictive energy of any situation, the most important 'tool' is the elicitive worker. In this spirit, we hope that this article contributes to the elicitive worker's refinement of skills and abilities with the aim of recovering and maintaining his/ her own clarity, authenticity and balance and so be able to provide the best possible safe space for parties to find courses of action to transform conflicts.

\section{References}

BUZAN, Tony (2010). The mind map book: unlock your creativity, boost your memory, change your life. London: Pearson.

DIETRICH, Wolfgang (2012). Interpretations of peace in history and culture. (Many Peaces vol. 1). J. Koppensteiner (trans.). London: Palgrave Macmillan. http://dx.doi.org/10.1057/9780230367715

DIETRICH, Wolfgang (2013). Elicitive conflict transformation and the transrational turn in peace politics. (Many Peaces vol. 2). W. Sützl; V. Hindley (trans.). London: Palgrave Macmillan.

http://dx.doi.org/10.1057/9781137035066

DIETRICH, Wolfgang (unpublished). Elicitive conflict mapping. (Many Peaces vol. 3). Wien/Münster: LIT Verlag.

DIETRICH, Wolfgang; SÜTZL, Wolfgang (2006). "A call for many peaces". In: W. DIETRICH; J. ECHAVARRIA; N. KOPPENSTEINER (eds.). Schlüsseltexte der Friedensforschung / Key Texts of Peace Studies / Textos Claves de la Investigación para la Paz. Wien: LIT Verlag. Pages 282-301.

ECHAVARRÍA, Josefina; INGRUBER, Daniela; KOPPENSTEINER, Norbert (2011). “Conclusions". In: W. DIETRICH; J. ECHAVARRÍA; G. ESTEVA; D. INGRUBER; N. KOPPENSTEINER (eds.). The Palgrave international handbook of peace studies: a cultural perspective. London: Palgrave Macmillan. Pages 597-606.
LEDERACH, John Paul (1997). Building peace: sustainable reconciliation in divided societies. Washington DC: United States Institute of Peace Press.

LEDERACH, John Paul (2003). The little book of conflict transformation. Intercourse, PA: Good Books.

LEDERACH, John Paul (2005). The moral imagination: the art and soul of building peace. Oxford: Oxford University Press.

http://dx.doi.org/10.1093/0195174542.001.0001

ROGERS, Carl (1995). On becoming a person. A therapist's view of psychotherapy. Boston: Mariner Books. http://dx.doi.org/10.1207/s15327752jpa6402 12

ROGERS, Carl R.; FARSON, Richard E. (1987). "Active listening" [online article]. [Date of consultation: 13 October 2013].

ROSENBERG, Marshall (2005). Nonviolent communication: a language of life. Encinitas: Puddle Dancer Press.

WILBER, Ken (2000). Sex, ecology, spirituality: the spirit of evolution. Boston: Shambala. 


\section{Recommended citation}

ECHAVARRÍA ÁLVAREZ, Josefina (2014). "Elicitive Conflict Mapping: A Practical Tool for Peacework" [online article]. Journal of Conflictology. Vol. 5, Iss. 2, pp. 58-71. Campus for Peace, UOC. [Consulted: $\mathrm{dd} / \mathrm{mm} / \mathrm{yy}$ ].

http://www.uoc.edu/ojs/index.php/journal-of-conflictology/article/view/vol5iss2-echavarria/vol5iss2-echavarria-en

DOI: http://dx.doi.org/10.7238/joc.v5i2.1986

ISSN 2013-8857

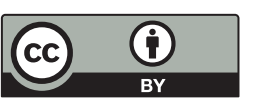

The texts published in this journal are - unless indicated otherwise - covered by the Creative Commons Spain Attribution 3.0 licence. You may copy, distribute, transmit and adapt the work, provided you attribute it (authorship, journal name, publisher) in the manner specified by the author(s) or licensor(s). The full text of the licence can be consulted here: http://creativecommons.org/licenses/by/3.0/es/deed.en.

- About the author

Josefina Echavarría Álvarez

josefina.echavarria@uibk.ac.at

Core Faculty member. MA Program and UNESCO Chair for Peace Studies. University of Innsbruck, Austria. 